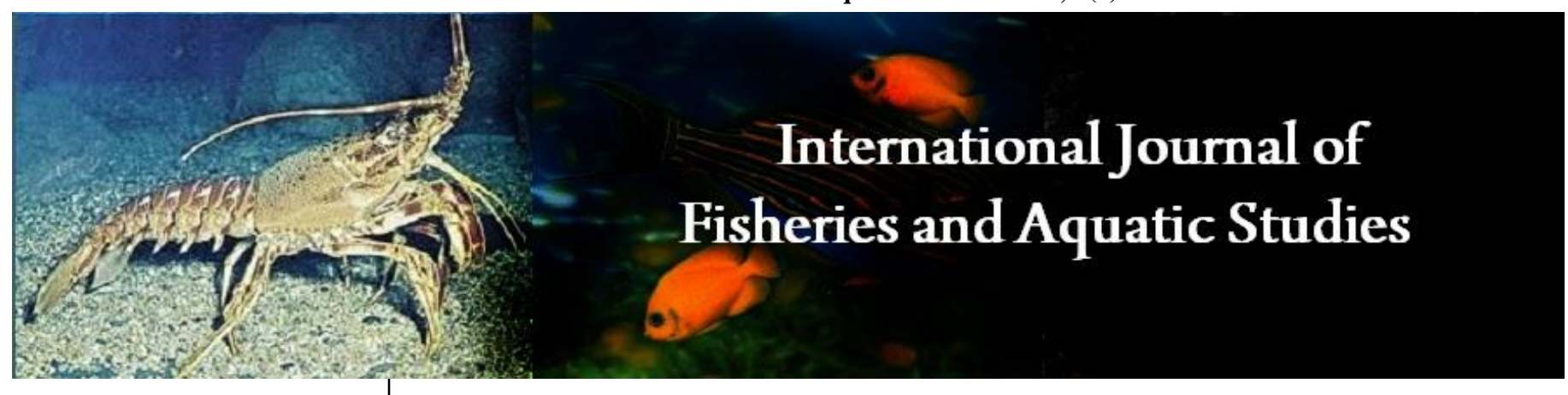

E-ISSN: 2347-5129

P-ISSN: 2394-0506

(ICV-Poland) Impact Value: 5.62

(GIF) Impact Factor: 0.549

IJFAS 2021; 9(3): 174-179

(C) 2021 IJFAS

www.fisheriesjournal.com

Received: 08-02-2021

Accepted: 11-03-2021

Dr. Brij Mohan Singh

Associate Professor, S. K. Govt.

Girls College, Sikar, Rajasthan,

India
Corresponding Author: Dr. Brij Mohan Singh

Associate Professor, S. K. Govt. Girls College, Sikar, Rajasthan, India

\section{Histopathological study of Channa gachua exposed to sublethal concentration of malathion}

\section{Dr. Brij Mohan Singh}

DOI: https://doi.org/10.22271/fish.2021.v9.i3c.2472

\section{Abstract}

This is well established fact that the exposure of pesticide leads to the significant physiological and histological changes in aquatic fauna. Therefore, ecotoxicology and histopathology have become the important areas of research for scientists, now a days. In order to investigate histopathological effects of synthetic pyrethroids, Skin, Liver, kidney, gills, and spleen of Channa gachua were examined after exposure to sublethal and acute concentration of melathion $(0.8$ and $1.6 \mathrm{mg} / \mathrm{L})$ for 20 days. Fishes showed degenerative, necrotic changes and congestion of blood vessels in gill filament. Severe degeneration in secondary gill lamellae, separation of gill filament from basement membrane, proliferation of mucus cells and atrophy of gill filament were seen. Hyperplasia was found as an increased number of epithelial cells at the distal or basal portions of kidney. Few nephrons had obstructed glomerular capillary and detachment of the tubular epithelium with the surrounding tissue. Necrosis was present in hematopoietic tissue, glomerular cells, and tubular cells. Melanomacrophage centers (MMC) were scattered throughout liver and spleen. Exudates and necrosis in the splenic white pulp were observed. The liver had a low number of necrotic hepatocytes and enlarged hepatic perisinusoidal areas containing eosinophilic material. Vacuolar dystrophy of hepatocytes and hypertrophy of hepatocytes were also observed. Fish showed serious skin lesions but did not show any behavioural abnormality as compared to controlled group. Their histological recovery was also examined for next 30 days. These changes which observed during exposure were reversed after 30 days of recovery period.

\section{Keywords: Malathion, Toxicity, Histopathology, Pesticides, Channa gachua}

\section{Introduction}

Exposure of insecticides influences some important physiological functions of fish. It greatly affects fish production and human health too through ecological cycling and biological magnification. Accumulated pesticide acts as a prooxidants and enhances prooxiradial generation by reacting with oxygen. Indiscriminate use of these two pesticides kills not only the pests but also a wide variety of non-target organisms like fish and other aquatic fauna. Last few years have witnessed about multi fold increase in the use of synthetic pesticides. Much of the pesticides released in to the environment never find their target organisms and drains in the home of the fishes ${ }^{[1]}$ and adversely affect other invertebrates of aquatic environment ${ }^{[2]}$.

Malathion $\left(\mathrm{C}_{10} \mathrm{H}_{19} \mathrm{O}_{6} \mathrm{PS}_{2}\right)$ is a broad spectrum organophosphate insecticide which controls insects by contact action and by ingestion of Thiodan-treated plant material. Malathion is a chemical compound which is used as a racemate. It is a pesticide that is used widely in agriculture, in homes, and in public health related pest control programs such as malaria eradication by the govt. of India. In the India, today it is the most commonly used organophosphate insecticide in agriculture fields.

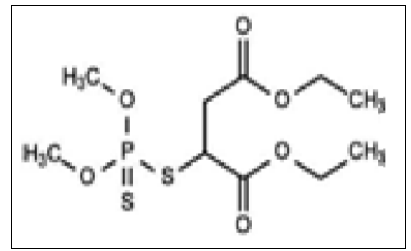

Malathion 
The acute toxicity of cypermethrin and $\lambda$ Cyhalothrin to Channa punctatus has been reported by [3]. Acute toxicity of Chlorantraniliprole to fresh water fish (Channa gachua) affects regard physiology and pathological changes and their bioconcentration and bioaccumulation in fish tissue ${ }^{[4]}$. Agricultural runoff of rain and irrigation water introduces pesticides into the aquatic environment, where it poses significant toxicological risks to resident organisms [5]. According to ${ }^{[6]}$ pesticide contamination severely affects aquatic fauna in turn whole food chain including human being. Although toxicity mechanisms of Malathion and Methiocarb were extensively studied by many researchers but still so many gaps are there. Histopathological studies have been conducted to help establish a relationship between insecticide exposure and various biological responses. This study was aimed to determine the histopathological effects of sublethal and acute concentrations of malathion pesticide on gills, liver, spleen, skin, and kidney of Channa gachua fish.

\section{Materials and Methods \\ 1. Fish}

Fresh water fish Juveniles of Channa gachua $(20 \pm 5 \mathrm{~g} ; 5.0 \pm$ $0.1 \mathrm{~cm}$; Mean \pm SD) were obtained from a local water body Kot dam, Sikar and held in 2 closed recirculating systems (200L) for at least 15 days to acclimatize to laboratory conditions. During the acclimation period, about half amount of the water in both recirculating systems were changed alternate day. Entire batch of fish was discarded if mortality exceeds $6 \%$ during acclimatization. Fishes were held in 12 hour light and 12 hour darkness period throughout experimentation. During acclimatization and during toxicity tests, fishes were fed twice a day with commercial fish pellets.

\section{Pesticides}

Malathion sold as suthion or cythion technical peckaging type the insecticide was purchased from the local market of Sikar City, Rajasthan.

\section{Water Quality}

The water used for acclimatization and conducting experiment was clear unchlorinated and unpolluted ground water and the hydrographic conditions of water shown in table-1.

Table 1: Physico-chemical quality parameters of water

\begin{tabular}{|c|c|}
\hline Physicochemical parameters & Amount \\
\hline Turbidity (NTU) & 122 \\
\hline Electrical conductivity (in mho) & $812 \mu \mathrm{mho} / \mathrm{cm}$ \\
\hline $\mathrm{pH}$ & $7.5 \pm 0.2$ \\
\hline Temperature ${ }^{\circ} \mathrm{C}$ & $15.2 \pm 4$ \\
\hline Total hardness $(\mathrm{mg} / \mathrm{l})$ & $112 \pm 16$ \\
\hline Calcium hardness $(\mathrm{mg} / \mathrm{l})$ & $88 \pm 5$ \\
\hline Magnesium hardness (mg/l) & $49 \pm 2$ \\
\hline Nitrate $(\mathrm{mg} / \mathrm{l})$ & $2.3 \pm 0.9$ \\
\hline Sulphate $(\mathrm{mg} / \mathrm{l})$ & 0.3 \\
\hline Chloride $(\mathrm{mg} / \mathrm{l})$ & 33 \\
\hline Fluoride $(\mathrm{mg} / \mathrm{l})$ & Trace \\
\hline Dissolved oxygen (ppm) & 8.0 \\
\hline
\end{tabular}

Its characteristics in each treatment were measured periodically. Various physicochemical characters of water of the container were estimated as per standard method of APHA [7]. Winkler method was used to measure dissolved oxygen in water. Water temperature and $\mathrm{pH}$ were determined by thermometer and $\mathrm{pH}$ meter respectively.

\section{Experimental Protocol}

The fishes were exposed to pesticides, must be done after making them free from external parasites. After acclimation, fish from one of the acclimation tanks were randomly transferred to one of $30 \mathrm{~L}$ glass aquaria containing $25 \mathrm{~L}$ of static water. Quadruplicate random groups of 10 fish each were subjected to experimentation for 20 days in static fresh water containing 0.8 or $1.6 \mu \mathrm{g} / \mathrm{L}$ Malathion. Doses selected were based on survivability responses assessed earlier [8]. Test solution of Malathion was prepared from commercial formulations containing $32.9 \%$ and $50 \%$ active ingredient, respectively. Quadruplicate aquaria were designated for each concentration of Malathion. The pesticides were dissolved in distilled water $(100 \mathrm{ml})$ and then mixed in fish aquaria.

About half of the test solutions were renewed each day. To avoid the toxicity in experiment, water in each aquarium was periodically aerated by aerator. At the end of the 20 days of sublethal toxicity tests, fish were transferred to flow-through tanks to observe further effects of Malathion for 20 days of exposure. At the end of the 20 days of recovery, 10 fish were sampled for histopathological tests.

\section{Histopathology}

After 20 days of exposure, 5 fish from the experimental and control groups were anesthetized with a dose $(2 \mathrm{gm} / \mathrm{L})$ of MS222 and then the second gill arch, liver, spleen, trunk kidney, and skin were carefully removed and preserved in $10 \%$ neutral-buffered formalin (NBF) for 48 hours. After the 30-day recovery period, the same organs were taken from rest of the fishes. Organs were rinsed with distilled water and then in 4 changes of $70 \%$ ethanol, and stored in $70 \%$ ETOH until further processing. The organs were dehydrated, cleared, infiltered and then sectioned of about $5 \mu \mathrm{m}$ thickness. For this purpose isopropanol, xylene and paraffin were used. Sections were stained with hematoxylin and eosin, and examined with a high power compound microscope in zoological laboratory of S.K. Govt. College, Sikar (India).

\section{Results}

Three fishes were died during the acclimation period before Malathion exposure, and no fish died during toxicity tests. Fish exposed to sublethal concentration of malathion did not show any behavioral abnormality compared to control groups (Figure-1).

Histopathological changes were not evident in liver, kidney, spleen and skin of fish exposed to sublethal concentration of malathion for 20 days. In the higher dose of malathion, the only lesion observed were in the gills, characterized by separation of epithelium from gill lamellae and the space under the epithelium filled with eosinophilic material (Table2). Mild histological lesions were observed in gills, liver, spleen, and trunk kidney of Channa gachua exposed to sublethal concentration of Malathion. Serious lesions were observed in the gills of fish exposed to the higher concentration (acute) i.e. $1.6 \mu \mathrm{g} / \mathrm{L}$ of pesticide. Marathon's effect consisted primarily of epithelial lifting, which is characterized by a lifting of the outer layer of the lamellar epithelium with the space under the epithelium filled with eosinophilic material. Hyperplasia was present as an increased number of epithelial cells at the distal or basal portions. Normal gills were seen in controlled group (Figure-2) but when fishes were exposed to sublethal concentration of Malathion pesticides they show degenerative changes in gill filament and congestion of blood vessels in gill filament. 
Degenerative and necrotic changes in epithelium of gill filament, severe degeneration in secondary gill lamellae, separation of gill filament from basement membrane, curling of secondary lamellae, proliferation of mucus cells and atrophy of gill filament. (Figure 3, A - I).

Skin lesions were observed in Channa gachua of experimental group during acute toxicity of Malathion (Figue4). In the trunk kidney, no lesion was noticed in controlled group (Figure-5), but when it exposed to Malathion had enlarged sinusoids within an apparently decreased amount of hematopoietic tissue. Some nephrons had obstacled glomerular capillaries and separation of the renal tubular epithelium from connective tissue. Necrosis was found in hematopoietic tissue, glomerular cells, and tubular cells. Glomeruli had eosinophilic exudate (Figure-6).

The liver had a low number of necrotic hepatocytes and enlarged hepatic perisinusoidal areas containing eosinophilic material. Vacuolar dystrophy of hepatocytes and hypertrophy of hepatocytes were also observed in liver (Figure- 7\&8). Melanomacrophage centers (MMC) were scattered throughout spleen in fish. Exudates and necrosis in the splenic white pulp were observed (Figure- 10) which never seen before in controlled group (Figure-9). Histopathological lesions explained above were not seen in control fish except for MMCs, which were less common and smaller than in the Malathion-exposed fish. The fish that survived the 21-day Malathion toxicity tests and were then transferred to other flow-through tanks for observations did not have any abnormal behavior. After histopathological examinations of survivors, fish had no lesions in gills, kidney, spleen, liver, or skin.

Table 2: Histopathological results of pesticide on fish organs

\begin{tabular}{|c|c|c|}
\hline $\begin{array}{l}\text { Histopathological } \\
\text { Effects }\end{array}$ & $\begin{array}{c}\text { Sublethal concentration of } \\
\text { Malathion }(0.8 \mu \mathrm{g} / \mathrm{L})\end{array}$ & $\begin{array}{l}\text { Acute toxicity of Malathion } \\
(1.6 \mu \mathrm{g} / \mathrm{L})\end{array}$ \\
\hline $\begin{array}{c}\text { Gills } \\
\text { (Figure }-2 \& 3 \text { ) }\end{array}$ & $\begin{array}{l}\text { 1. Fishes showed degenerative changes and } \\
\text { congestion of blood vessels in gill filament. } \\
\text { 2. Degenerative and necrotic changes in } \\
\text { epithelium of gill filament, } \\
\text { 3. Severe degeneration in secondary gill } \\
\text { lamellae, separation of gill filament from } \\
\text { basement membrane, }\end{array}$ & $\begin{array}{l}\text { 1. Lifting of the outer layer of the lamellar epithelium with the space under } \\
\text { the epithelium filled with eosinophilic material. } \\
\text { 2. Hyperplasia was present as an increased number of epithelial cells at the } \\
\text { distal or basal portions, when acute dose of insecticide was applied. }\end{array}$ \\
\hline $\begin{array}{c}\text { Skin } \\
\text { (Figure- 4) }\end{array}$ & Mild skin lesions appeared & Serious skin lesions were observed \\
\hline $\begin{array}{c}\text { Kidney } \\
\text { (Figure- 5\&6) }\end{array}$ & No histopathological changes & $\begin{array}{l}\text { 1. The trunk kidney showed enlarged sinusoids within an apparently } \\
\text { decreased amount of hematopoietic tissue. } \\
\text { 2. Some nephrons had occluded glomerular capillaries and separation of the } \\
\text { renal tubular epithelium from the surrounding connective tissue. } \\
\text { 3. Necrosis was present in hematopoietic tissue, glomerular cells, and tubular } \\
\text { cells. } \\
\text { 4. Glomeruli had eosinophilic exudation }\end{array}$ \\
\hline $\begin{array}{c}\text { Liver } \\
\text { (Figure-7\&8) }\end{array}$ & Mild histological lesions & $\begin{array}{l}\text { 1. The liver had a low number of necrotic hepatocytes and enlarged hepatic } \\
\text { perisinusoidal areas containing eosinophilic material. } \\
\text { 2. Vacuolar dystrophy of hepatocytes and hypertrophy of hepatocytes were } \\
\text { also observed. }\end{array}$ \\
\hline $\begin{array}{c}\text { Spleen } \\
\text { (Figure- 9\&10) }\end{array}$ & Mild histological lesions & $\begin{array}{l}\text { 1. Melanomacrophage centers (MMC) were scattered throughout spleen in } \\
\text { fish. } \\
\text { 2. Exudates and necrosis in the splenic white pulp were observed. }\end{array}$ \\
\hline
\end{tabular}

\section{Discussion}

Histopathology is an important diseases diagnostic tool in fish. The exposure of fish to insecticide is likely to induce a number of lesions in different organs Gills ${ }^{[9]}$, kidney ${ }^{[10]}$, and liver ${ }^{[11]}$ are suitable organs for histological examination in order to determine the effect of pollution. The exposure of aquatic organisms to very low levels of pesticides may result in various biochemical, physiological, and histological alterations in their vital tissues. Author found that most of the lesions were related to exposure to malathion. Lamellar lifting was observed after exposure to higher concentration of malathion. Furthermore, lamellar fusion was only observed in fish exposed to $1.6 \mu \mathrm{g} / \mathrm{L}$ malathion. Increasing concentrations of malathion from sublethal to acute, melanomacrophage centers were scattered throughout the trunk kidney, head kidney, and spleen (Capkin et al., 2006). However, correlation of different concentrations of malathion and histopathological changes were weak in fish. ${ }^{[12,13]}$ both found similar results in their research.

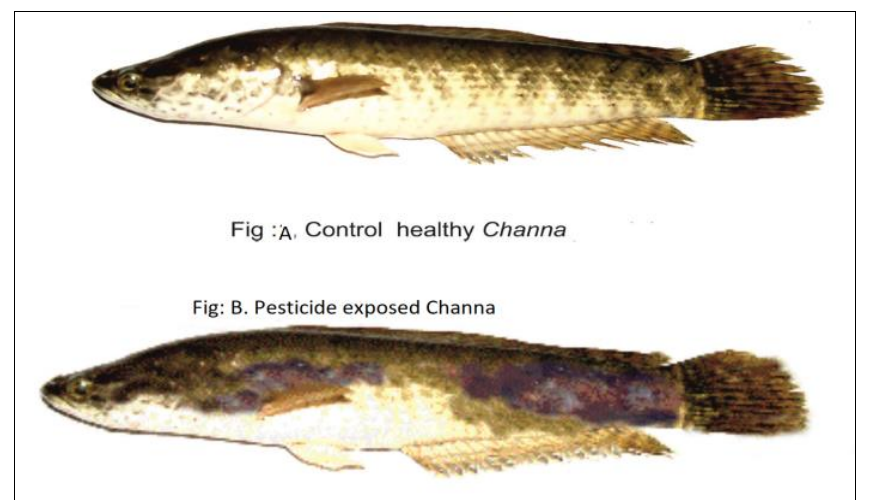

Fig 1AB: Control healthy Channa gachua

B. Insecticides exposed Channa gachua (Source: Simple micrograph)

Histopathological study of EUS (Epizootic ulcerative syndrome) infected Channa gachua showed epidermal loss exposing dermis, degenerating muscle as well as liver cells and kidney exhibited tubular necrosis, interstitial lymphocyte infiltration, haemorrhage and shrinkage of glomeruli [14]. Toxic substances can injure gills, thus reducing the oxygen 
consumption and disrupting the osmoregulatory function of aquatic organisms ${ }^{[15]}$. Lesions were observed in gills, liver, spleen, and trunk kidney (but not skin) of rainbow trout exposed to either concentration of endosulfan. In a study, no concentration-related effect observed on the histopathological lesions and after 30 days of recovery, fish had no histological lesions in gills, kidney, spleen, liver, or skin because all the changes observed during exposure were reversible ${ }^{[16]}$.

In the present study, exposure of rainbow trout to Malathion resulted in structural alterations of the gill lamellae including edema, separation of epithelium from lamellae, lamellar fusion, and swelling of the epithelial cells. Similar results were also observed by ${ }^{[17]}$ in Heteropneustes fossilis. ${ }^{[18]}$ found that sublethal concentration of endosulfan can not only cause damage in muscle, kidney, gills, and liver but also alter the metabolic and physiological activities of Labeo. The results of these studies clearly indicate that sublethal concentration of malathion has diverse effects on fish gills. Gill lesions (edema with lifting of lamellar epithelium and hyperplasia of lamellar epithelium) found in the present study suggest that malathion causes injury to the gills and increases respiratory diffusion distance. In the present study, gills were found to be the most seriously affected organs compared to liver, spleen, trunk kidney, and skin, perhaps because of the direct contact with the insecticides.

The liver has the ability to degrade toxic compounds, but its regulating mechanisms can be overwhelmed by elevated concentrations of these compounds, and could subsequently result in structural damage ${ }^{[19]}$. In the present study Malathion exposed fish had decreased amount of hematopoietic tissue in the trunk kidney, necrosis in hematopoietic tissue, glomerular cells, and tubular cells. Also the liver had necrosis and hypertrophy. Similarly ${ }^{[19-20]}$ found that organo-chlorines had behavioral disturbances and hepatic and renal injury when fish were exposed to sublethal concentrations of Malathion. Malathion reduces reproductive performance and enhances oxidative stress at subcellular level including lipid peroxidation and oxidative damage in Channa punctatus [21]. Similar observations have been made in the whitefish (Coregonus clupeaformis) exposed to nickel ${ }^{[22]}$ and in lake trout (Salvelinus namaycush) exposed to lindane ${ }^{[23]}$. In the present study, the concentrations of malathion tested did not cause any histological lesion in liver, spleen, skin, and trunk kidney of Channa gachua.

\section{Conclusion}

From the above study, it can be concluded that Malathion is a harmful pesticide for the fishes as well as other aquatic flora and fauna. The exposure of Malathion pesticide can cause serious damages in gills, liver, spleen, and trunk kidneys of Channa gachua (Table-2). After 30 days of recovery, there was no histological lesion observed in gills, kidney, spleen, liver, or skin of fish. Therefore all the changes observed during exposure were reversible.

\section{Acknowledgments}

Author is highly indebted to the department of zoology and chemistry, S. K. Government Girls College, Sikar (Rajasthan, India) for providing facilities of limnological and hydrobiological experimentations. $\mathrm{He}$ is very greatful to pathological laboratory of Sony Hospital, Sikar for histopathological test of different fish organs and providing facilities to take photographs.
He is also thankful for all those who helped directly or indirectly in the experimentation of the research work.

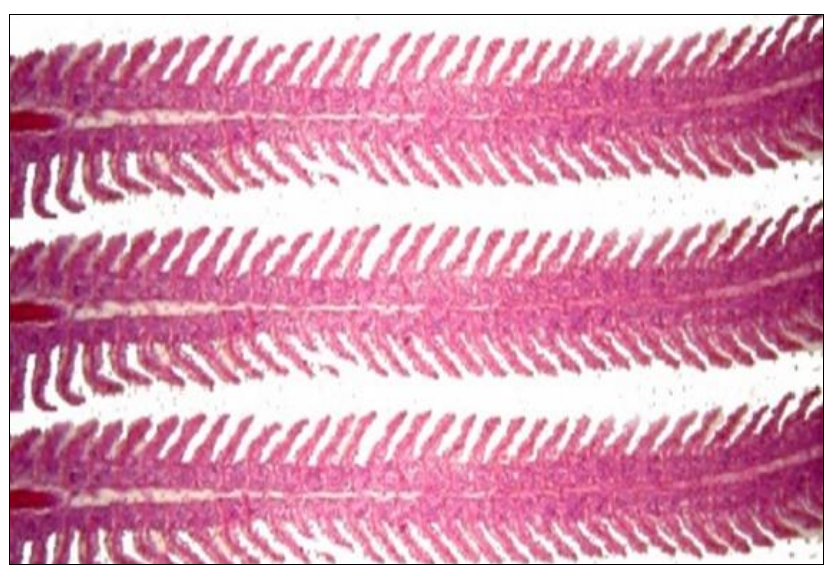

Fig 2: A Gill lamellae of healthy Channa gachua (Source: confocal microscopy)
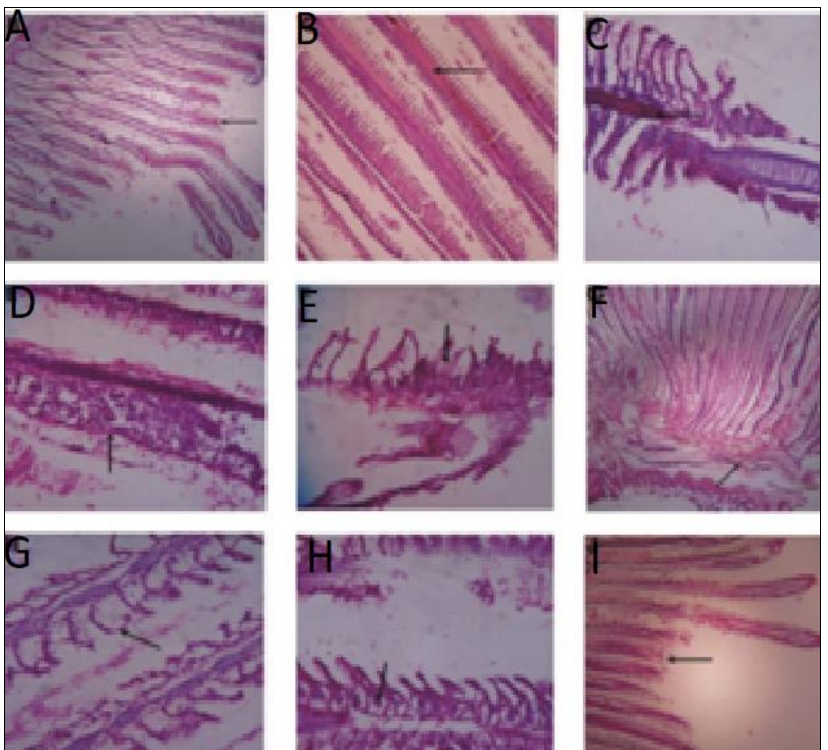

Fig 3: When fish were exposed to sublethal concentration of pesticides A. shows degenerative changes in gill filament and congestion of blood vessels in gill filament B. degenerative and necrotic changes in epithelium of fill filament $\mathrm{C}$. severe degeneration in secondary gill lamellae D\& E separation of gill filament from basement membrane, F. curling of secondary lamellae G. proliferation of mucus cells and H \&I. atrophy of gill filament. (Source: Simple micrograph)

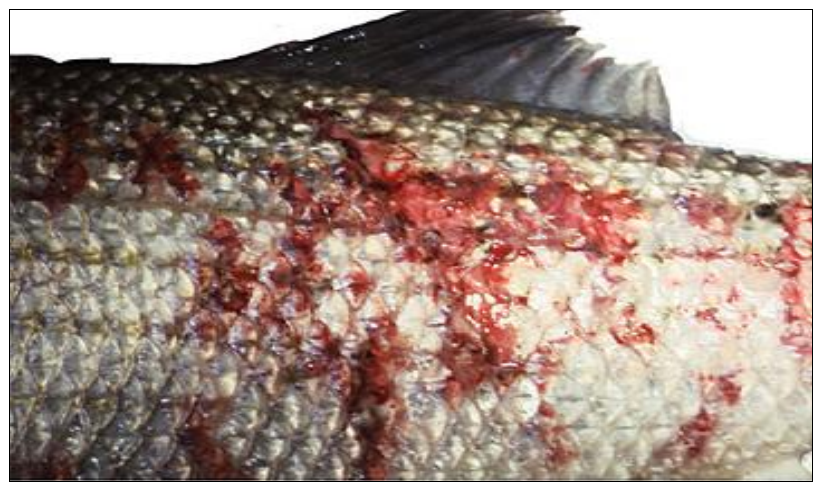

Fig 4: Skin lesions due to acute toxicity of malathion in Channa gachua fish. (Source: Simple micrograph) 


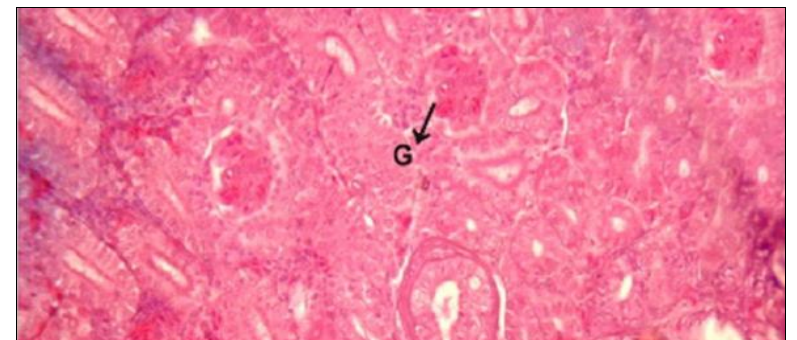

Fig 5: Channa showing normal Kidney $(\mathrm{G}=$ Glomerulus) (Source: High power micrograph)

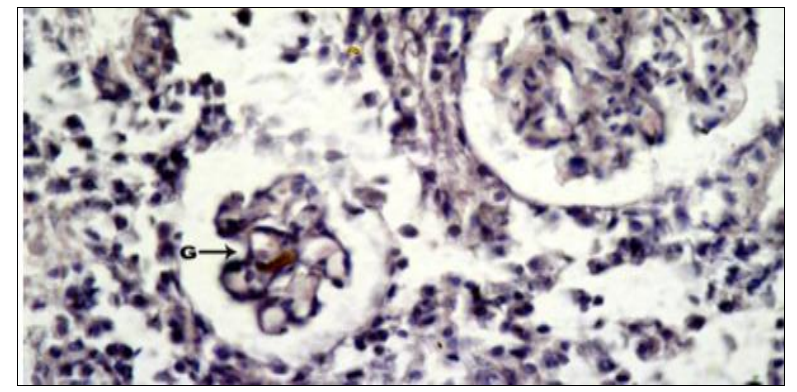

Fig 6: Enlarged sinusoids within an apparently decreased amount of hematopoietic tissue in kidney of Channa fish. (Source: confocal microscopy)

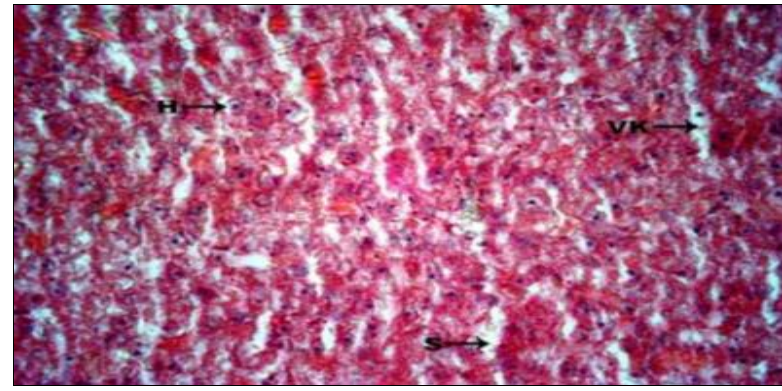

Fig 7: Normal liver cells (Source: High power micrograph)

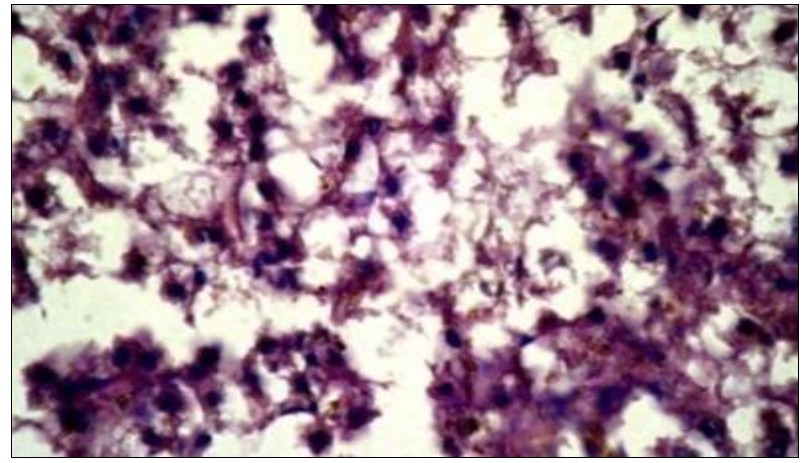

Fig 8: Malathion induced alterations in Channa liver (Source: confocal microscopy)

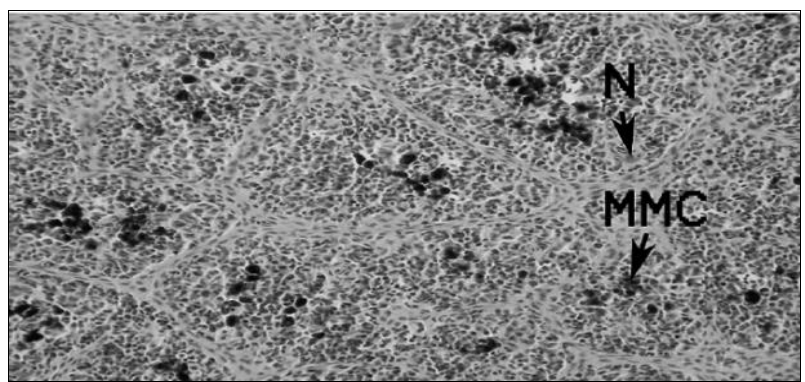

Fig 9: Normal spleen showing the red and white pulp melano macrophage centers (MMC), necrosis (N) (Source: High power micrograph)

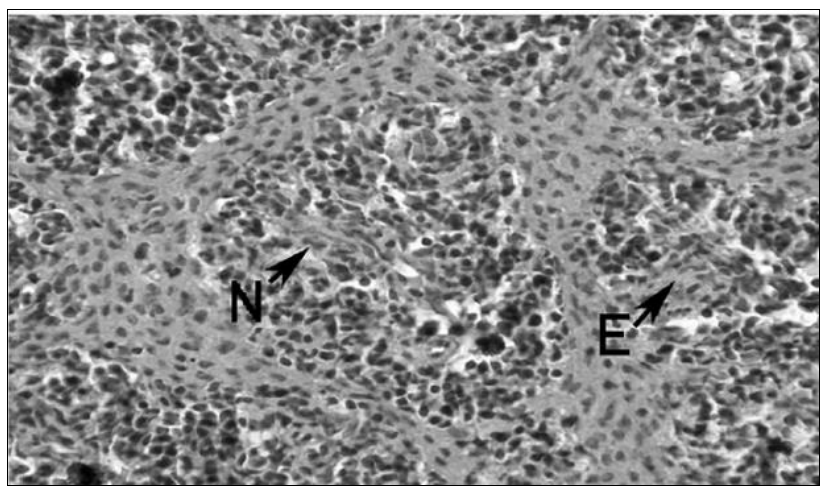

Fig 10: Spleen showing exudate in white pulp (E), and necrosis were observed in melathion exposed fish (Source: confocal microscopy)

\section{References}

1. Pimentel D, Edwards CA. "Pesticides and ecosystems". Bioscience 1982;32(7):595-600.

2. Burkepile DE, Moore MT, Holland MM. "Susceptibility of five non-target organisms to aqueous diazinon exposure Bull". Environ Contam Toxicol. 20006411421GoogleScholar | Crossref | Medline | ISI

3. Kumar A, Sharma B, Pandey R. "Preliminary evaluation of the acute toxicology of cypermethrin and $\lambda$ cyhalothrin to channa punctatuts". J. bull Environ. Contam. Toxicol. 2007;79B:585-595.

4. Nagaraju Bantu, Venkata Rathnamma Vakita. "Acute toxicity of chlorantraniliprole to freshwater fish Channa gachua (Bloch)". Advances in Zoology and Botany.; 2013;1(4):78-82.

5. Scott GI, Fulton MH, Moore DW. "Agricultural insecticide runoff effects on estuarine organisms: correlating laboratory and field toxicity testing with ecotoxicological biomonitoring Charleston, SCU.S." National Marine Fisheries Service, Southeast Fisheries Science Center, Charleston Laboratory Report \#CR813138-01-1,Google Scholar 1990.

6. Svensson BG, Hallberg T, Nilson. "A Parameters of immunological competence subjects with high consumption of fish contaminated with persistent organochlorine compounds" Int Arch Occup Environ Health1994 653518, Google Scholar | Crossref | Medline | ISI.

7. American Public Health Association (APHA) "American Water Works Association (AWWA) and Water Environment Federation (WEF)", Washington DC; USA. 2005.

8. Capkin E, Altinok I, Karahan S. "Water quality and fish size affect toxicity of Malathion, an organochlorine pesticide, to rainbow trout", Chemosphere 2006, 6417931800 Google Scholar | Crossref | Medline | ISI

9. Poleksic V, Mitrovic-Tutundzic V, Müller R, Lloyd R. "Fish gills as a monitor of sublethal and chronic effects of pollution Sublethal and Chronic Effects of Pollutants on Freshwater Fish" Oxford, UKFAO, Fishing News Books 339352 Google Scholar, 1994.

10. Bucher F, Hofer R. "The effects of treated domestic sewage on three organs (gills, kidney, liver) of brown trout (Salmo trutta) Water", 1993, 27255261Google Scholar | Crossref | ISI.

11. ICES (International Council for the Exploration of the Sea) "Special Meeting on the Use of Liver Pathology of Flatfish for Monitoring Biological Effects of Contaminants" International Council for the Exploration 
of the Sea, Copenhagen Google Scholar 1997.

12. Dalela RC, Bhatnagar MC, Tyagi AK, Verma SR. "Histological damage of gills in Channa gachua after acute and subacute exposure to Malathion and rogor" Mikroscopie 1979353017 Google Scholar | Medline

13. Trickle bank KA. "Histological alterations in fish from Sydney reefs: possible biomarkers for environmental effects" Biomarker 200162632 Google Scholar | Crossref | Medline | ISI

14. Laharia R, Patel P. "Histological changes in skin and gill of fresh water EUS infected fish Channa gachua" 'Environment conservation journal. 2020;21(1-2):75-84, DOI:

15. Saravana Bhavan P, Geraldine P. "Histopathology of the hepatopancreas and gills of the prawn Macrobrachium malcolmsonii exposed to Malathion" Aquat Toxicol 200050331339 Google Scholar | Crossref | Medline | ISI

16. altinok I, capkin E. "Histopathology of Rainbow Trout Exposed to Sublethal Concentrations of Methiocarb or Endosulfan" Toxicologic Pathology, 2007;35:405-410. Society of Toxicologic Pathology, DOI: 10.1080/01926230701230353.

17. Mutta H, Munshi JSD, Roy PK, Singh NK, Adhikari S, Killius J. "Ultrastructural changes in the respiratory lamellae of the catfish, Heteropneustes fossilis after sublethal exposure to malathion", Environmental Pollution 1996;92(3):329-341.

18. Brij Mohan Singh." Endosulfan mediated some physiological and biochemical changes in a fresh water fish", Int. J. of. Life Sciences 2020;8(2):317-326. (IJLSci, ISSN:2320 7817 www.ijlsci.in.

19. Bruslé J, Gonzàlez I, Anadon G, Munshi JSD, Dutta HM. "The structure and function of fish liver" Fish Morphology, NewYork. Science Publishers Inc Google Scholar 1996.

20. Hallenbeck WH, Cunningham-Burns KM. "Pesticides and Human Health" Springer-Verlag, New York School of Public Health Google Scholar | Crossref 1985.

21. Brij Mohan Singh. "Pyrethroid Mediated Some Macromolecular and Biochemical Changes in Fresh Water Teleost". Research \& Reviews: A Journal of Toxicology 2020;10(2):14-21. www.stmjournals.com (ISSN: 2349-1264).

22. Ptashynski MD, Pedlar RM, Evans RE, Wautier KG, Baron CL, Rao DMR. "AS Toxicity, biotransformation, and elimination of Malathion in Anabas testudineus (Bloch)" Ind J. Exp Bio 11980186645 Google Scholar | Medline | ISI.

23. Gill TS, Pant JC, Pant J. "Gill, liver and kidney lesions associated with experimental exposures to carbaryl and dimethoate in the fish (Puntiusonchonius am.)" Bull Environ Contam Toxicol 198841718 Google Scholar | Crossref | Medline | ISI. 